\title{
Essay Versus Multiple-Choice: A Perspective from the Undergraduate Student Point of View with its Implications for Examination
}

\author{
Çoktan Seçmeliye karşı Kompozisyon: Lisans Öğrencilerinin Görüşlerinden Bir Prespektif ve Sınav için Anlamı
}

\author{
Chandni Gupta ${ }^{1}$, Anuj Jain ${ }^{2}$, Antony Sylvan D'Souza ${ }^{1}$
}

${ }^{1}$ Department of Anatomy, Kasturba Medical College, Manipal University, Manipal, India
${ }^{2}$ Department of Anatomy, U.P. Rural Institute of Medical Sciences and Research, Saifai, Etawah, Uttar Pradesh, India

\section{ABSTRACT}

Objective: Essay and multiple-choice questions are both used to evaluate the mastery of academic courses. Each has their unique advantages as well as limitations. Multiple-choice tests provide an inexpensive means of evaluating the understanding of facts and concepts across an extensive range of topics whereas essay questions evaluate the organizational and productive skills in a more restricted content area. So, the aim of our study is to assess which types of questions are more effective in testing the cognitive skills from the point of view of undergraduate medical students.

Methods: The study is conducted on 250 undergraduate students who were admitted to the 1 st year program at Kasturba Medical College, Manipal. A preformed proforma containing few questions regarding essay and multiple choice questions is given to them to fill. The results are analyzed using simple statistics methods.

Results: The $59.5 \%$ students prefer multiple choice questions (MCQs) over essay question. 20.8\% don't prefer MCQs and 19.5\% were neutral. 24.1\% prefer essay questions over MCQs. $46.2 \%$ don't prefer essay questions and $29.5 \%$ were neutral.

Cocnlusion: From the results of our study it is evident that even students think that both types of questions should be there for their assessment because each type of questions has their advantages and disadvantages.

Key Words: Essay questions, multiple choice questions, examinations

\section{ÖZET}

Amaç: Kompozisyon ve çoktan seçmeli sorular akademik değerlendirme amacıyla kullanılmaktadır. Her birisinin avantajları olduğu kadar kısıtlı oldukları yerler de vardır. Çoktan seçmeli sınavlar, konuların geniş bir yelpazesinde gerçeklerin ve kavramların anlaşılmasını değerlendiren ucuz bir yol sağlarken, kompozisyon daha kısıtlı içerik alanında örgütsel ve üretken becerileri değerlendirir. Bu çalışmadaki amacımız, mezuniyet öncesi tıp öğrencilerinin bakış açısıyla hangi soru tiplerinin bilişsel becerileri daha etkin olarak ölçtüğünün değerlendirilmesidir.

Gereç ve Yöntem: Bu çalışma, Hindistan Manipal Kasturba Tıp Fakültesi'nde okuyan 250 Dönem 1 öğrencisi üzerinde yapılmıştır. Öğrencilerden kompozisyon ve çoktan seçmeli birkaç sorudan oluşan formu doldurmaları istenmiştir. Sonuçlar, temel istatistik yöntemler ile analiz edilmiştir.

Bulgular: Öğrencilerin \%59.5'i çoktan seçmeli soruları kompozisyona tercih etmiştir. Öğrencilerin $\% 20.8^{\prime} i$ çoktan seçmeli soruları hiç tercih etmemiş ve \%19.5'i ise kararsız kalmiştir. Öğrencilerin \%24.1'i kompozisyonu çoktan seçmeli sorulara tercih etmiştir ve \%46.2'si ise kompozisyonu tercih etmezken \%29.5'i kararsız kalmıştır.

Sonuç: Bu çalışmadan elde ettiğimiz sonuçlara göre, her iki tip soru da kendilerine ait avantaj ve dezavantajlara sahip olmaları nedeniyle öğrenciler her iki tip sorunun da kendilerinin değerlendirilmesinde kullanılmasını gerektiğini düşünmektedirler.

Anahtar Sözcükler: Kompozisyon, çoktan seçmeli sorular, sınavlar

Geliş Tarihi: 21.07.2015

Kabul Tarihi: 16.09.2015 


\section{INTRODUCTION}

Developing and testing the different types of cognitive skills (like knowledge and comprehension) of undergraduate medical students are the chief objectives of problem based learning. Essay Questions and Multiple Choice Questions (MCQ) both can be designed to test these skills (1). But the main aim of an exam is to accurately evaluate student learning. The literature tends to favor multiple-choice questions. Bridgeman B (1992) recommended that even though multiple-choice tests are less reliable due to guessing, they take less time to answer. Therefore an exam made up entirely of multiple-choice questions will contain more questions and therefore are more reliable than an exam containing fewer open-ended questions (2). Hassmen P and Hunt DP (1994) agreed, but also suggested that guessing shouldn't be discouraged because guesses are generally based at least partially on student knowledge of the relevant course content (3).

A weakness of essay questions cited by many authors is that they require subjective grading, and there will be various factors which are unrelated to answer, impacting exam scores. Lukhele et al. noted that essays become particularly unhelpful as a measure of learning if students were permitted to select the questions to answer from a longer list of questions provided, permitting the students to avoid topics they hadn't learned(4). But according to Scouller K, (2000) students learn deeply when they prepare their assignment essays which they perceived as assessing higher levels of cognitive processing(5)

So, both types of assessment have their pros and cons whether it is essay type or multiple choice types. Therefore the objective of this study is to assess which types of questions are more effective in testing the cognitive skills (mainly knowledge and comprehension) from the point of view of undergraduate medical students.

\section{MATERIALS AND METHOD}

The study is conducted in 2 months (November, December, 2014) on 250 undergraduate students who were admitted to the 1st year program at KMC, Manipal. Out of these 10 were absent and out of 240 students- 110 were males and 130 were females. Their age varies from 16-23 years. A preformed proforma containing 11 questions regarding essay and multiple choice questions is given to them to fill. The proforma was prepared by selecting questions from various study domains (6). The students responded to each statement by selecting "Disagree Strongly," "Disagree," "Neutral," "Agree" or "Agree Strongly." The results are analyzed using simple statistics methods.

\section{RESULTS}

The $59.5 \%$ of the students prefer MCQs over essay questions. $20.8 \%$ don't prefer MCQs and $19.5 \%$ were neutral. $24.1 \%$ prefer essay questions over MCQs. $46.2 \%$ don't prefer essay questions and $29.5 \%$ were neutral. Percentages of students answering various questions asked as essay and $M C$ questions is shown in Table 1.

The $60 \%$ of them reported that MCQs are less fair and they can't earn partial credits for marking. $21.6 \%$ disagree on this point and $18.3 \%$ were neutral. $60.8 \%$ reported that essay questions are easier to get marks from as students can earn partial credit by answering them. $17 \%$ disagree and $20.3 \%$ were neutral.

Table 1. Showing percentages of students answering the various questions asked on essay and MCQs

\begin{tabular}{|c|c|c|c|}
\hline \multirow[t]{2}{*}{ Questions } & \multicolumn{3}{|c|}{ Percentage } \\
\hline & Agree & Disagree & Neutral \\
\hline Multiple-choice easier: I only need to recognize correct answer & $60.4 \%$ & $1.2 \%$ & $18.33 \%$ \\
\hline $\begin{array}{l}\text { Multiple-choice easier: I might guess } \\
\text { correctly even if I don't know }\end{array}$ & $45.4 \%$ & $30 \%$ & $24.5 \%$ \\
\hline Essay less specific: Content knowledge results biased by writing skill & $50.4 \%$ & $19.5 \%$ & $30.1 \%$ \\
\hline $\begin{array}{l}\text { Multiple-choice harder: I need to know } \\
\text { minute details }\end{array}$ & $65 \%$ & $20.8 \%$ & $14.1 \%$ \\
\hline Essay harder: I must fully understand topic to produce good answer & $62.5 \%$ & $18.3 \%$ & $19.1 \%$ \\
\hline Essay more fair:More accurately show what I know/don't know & $54.5 \%$ & $20.4 \%$ & $25 \%$ \\
\hline
\end{tabular}

\section{DISCUSSION}

Two categories of examination that students usually encounter in their study are MCQs and essay examinations (7). It is generally assumed that MCQs focus on knowledge recall and essay questions test the higher cognitive skills. When the content of both assessments is matched the MCQ will correlate well with the essay questions and the former can precisely predict the clinical performance (8).

David AP found that the students generally prefer multiple-choice but become more enthusiastic about essays when they are well-prepared for exams (6). In our study also $59.5 \%$ of students prefer MCQs over essay questions. And $54.5 \%$ reported that essays are fairer. It shows what they know and what they don't.

Scouller $\mathrm{K}$ found that the vast majority of students preferred the assignment essay as the method of assessing their learning and provided well-thought-out pedagogical reasons for their decision. The assignment essay was primarily valued for encouraging the development of higher order intellectual abilities and skills (9).

Students perceived the multiple-choice examination as evaluating ability to recall factual information (lower levels of cognitive processing) and were more motivated to employ superficial approaches and aims when preparing for such an examination than when preparing for an essay assignment (10). Even from the results of our study, $60.4 \%$ of the students think that they have to just recognize the correct answer. $82.9 \%$ thought that they can easily eliminate the wrong answer. They don't have to deal with details about the topic. $45.4 \%$ students think they can guess the correct answer if they know a vlittle bit about the topic.
Birenbaum M and Feldman RA (1998) revealed that students with good knowledge skills, who have great confidence in their academic ability, tend to favor the essay type of assessment over the multiple-choiceexaminations (11). In our study $54.5 \%$ students think that essay is fairer. It shows what they know or what they don't.

\section{CONCLUSION}

In our study $59.5 \%$ students prefer MCQs over essay questions. For scoring marks, the $60 \%$ of students reported that on MCQs they can't earn partial mark credits. $60.8 \%$ reported that on essay questions they can get more marks. $60.4 \%$ reported that MCQs are easier and that they only need to recognize the correct answer for MCQs. $82.9 \%$ reported that on MCQs they can easily eliminate obviously wrong answers, so these factors hinder their learning.

$65 \%$ reported that MCQs are harder and that they need to know minute details about the subject. $62.5 \%$ reported that essay questions are harder and that they must fully understand the topic to produce good answer. 54.5\% reported that essay questions are fairer because it accurately shows what I know and what I don't know.

The result shows that for both type of questions they have to learn hard and these enhance learning. To conclude, even students think that both types of questions should be there for their assessment because each type of questions has their advantages and disadvantages.

\section{Conflict of interest}

No conflict of interest was declared by the authors 


\section{REFERENCES}

1. Khan MUZ, Aljarallah BM. Evaluation of Modified Essay Questions (MEQ) and Multiple Choice Questions (MCQ) as a tool for Assessing the Cognitive Skills of Undergraduate Medical Students. Int J Health Sci (Qassim) 2011; 5: 39-43.

2. Bridgeman B. A comparison of quantitative questions in open-ended and multiple-choice formats [Electronic version]. Journal of Educational Measurement 1992; 29: 253-71.

3. Hassmen P, Hunt DP. Human self-assessment in multiple-choice testing [Electronic version]. Journal of Educational Measurement, 1994; 31: 149-60.

4. Lukhele $\mathrm{R}$, Thissen $\mathrm{D}$, Wainer $\mathrm{H}$. On the relative value of multiplechoice, constructed response, and examinee-selected items on two achievement tests [Electronic version]. Journal of Educational Measurement 1994; 31:234-50.

5. Scouller K. The influence of assessment method on students' learning approaches: Multiple choice question examination versus assignment essay. Studies in Higher Education, 2000; 25:309-23.
6. David AP. Essay versus multiple-choice: student preferences and the underlying rationale with implications for test construction. Academy of Educational Leadership Journal. 2009; 13: 57-71.

7. Smith SN. \& Miller RJ. Learning approaches: examination type, discipline of study, and gender. Educational Psychology 2005; 25: 43 -53 .

8. Rabinowitz HK: The modified essay question: an evaluation of its use in a family medicine clerkship. Medical Education 1987, 21:114-8.

9. Scouller K. Students' perceptions of three assessment methods: assignment essay, multiple choice question examination, short answer examination. Research and Development in Higher Education. 1997; 20:646-53.

10. Demirci N. Turkish Prospective Teachers' Perspective of Different Types of Exams: Multiple Choice, Essay and Computerized-type Testing. Essays in Education special edition. 2007; 48-62.

11. Birenbaum $M$ \& Feldman RA. Relationships between learning patterns and attitudes towards two assessments formats, Educational Research, 1998; 40: 90-7. 